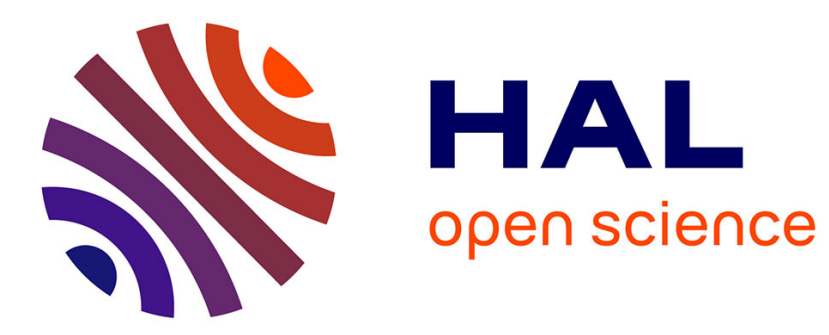

\title{
Graphical representation: an analytical and publication tool for electroacoustic music \\ Pierre Couprie
}

\section{To cite this version:}

Pierre Couprie. Graphical representation: an analytical and publication tool for electroacoustic music.

Organised Sound, 2004, 9 (1), pp.109-113. hal-01265027

\section{HAL Id: hal-01265027 \\ https://hal.science/hal-01265027}

Submitted on 2 Jan 2017

HAL is a multi-disciplinary open access archive for the deposit and dissemination of scientific research documents, whether they are published or not. The documents may come from teaching and research institutions in France or abroad, or from public or private research centers.
L'archive ouverte pluridisciplinaire HAL, est destinée au dépôt et à la diffusion de documents scientifiques de niveau recherche, publiés ou non, émanant des établissements d'enseignement et de recherche français ou étrangers, des laboratoires publics ou privés. 


\title{
Graphical representation: an analytical and publication tool for electroacoustic music
}

\author{
PIERRE COUPRIE \\ 5, rue Crespin du Gast, 75011 Paris, France \\ E-mail: pcouprie@noos.fr
}

\section{INTRODUCTION}

When, in 1998, I began my research into the analysis of electroacoustic music, analysis and representation were two distinct disciplines. One was an integral part of music research and the other was just a possible option for publication. Since this time, I have come across various analytical methods related to this type of music, from which I have developed a specific process. During this time, multimedia has slowly asserted its presence within the research domain: software has been developed and is now used by researchers. Nowadays, analysis can be found on media such as the CD-ROM or the Internet, and the simultaneous combination of sound, graphics and texts is very common. In this context, graphical representation seems to constitute a real tool for analysis and for the publication of electroacoustic music: henceforth, analysis and representation will be inseparable. Such an attitude will no doubt be very beneficial for music research. Indeed, representation raises new problems (relations between image and sound, the didactical aspect of a sound publication or even the boundary between musical research and creation) in relation to disciplines as yet little used (for example semiotics); so many possibilities that, I think, will encourage a real renewal of ideas in music research.

I suggest dividing my study of analytical representation into four steps. Such a procedure will enable a greater understanding of the reasons why representation could be a great pedagogical tool, not only to guide the listening of neophytes but also as an analytical tool, particularly appropriate to electroacoustic music.

\section{DIFFICULTIES IN ANALYSING ELECTROACOUSTIC MUSIC}

All researchers who have attempted to analyse electroacoustic music are familiar with the same basic problems. This is not to say that such problems do not exist in instrumental music but that the presence of a score softens or even hides them. However, in any analytical theory, it is essential that they be considered. Thus, the analysis of electroacoustic music forces us to address theoretical issues, until now often avoided.
It is possible to organise these problems into two categories: those specific to electroacoustic music and those related to analysis in general. In my first category I would include, on the one hand, the problem caused by the lack of a visual representation and, on the other, the difficulties related to the complexity of spectromorphological and spaciomorphological structures. ${ }^{1}$ The second category would encompass the problem of segmentation and that of the dualism of permanence/variation. Of course, all these different questions are related to each other, and I aim to show how graphical representation can help us to find solutions to some of them.

\section{WHAT IS A GRAPHICAL REPRESENTATION?}

Before looking more closely at some examples, I must first define what representation means to me. On the one hand, it is made up of the space in which representation can be found: the representational view. On the other, it consists of graphical or textual elements. Despite experimentation, it appears that a twodimensional plan is better than a three-dimensional one. Indeed, two dimensions make it easier to read the coordinates of the object (figure 1) while in a threedimensional plan, an object is often difficult to situate visually (figure 2). What is more, this difficulty is even more accentuated when dealing with animated representations.

Each of the representation's objects has a certain number of graphical characteristics, related to the sound criteria or sound structure they represent. As such, the shape, size, colours, as well as vertical and horizontal positioning are all related to criteria such as intensity, grain, height, spectral density or length. But before going into details regarding these associations, let us take a closer look at those graphical objects. I think it is possible to organise representations into two categories: iconic and symbolic. In similar fashion to the semiotician Claudine Tiercelin (Tiercelin 2002), I tend towards an interpretation of the Peirce theory,

${ }^{1}$ I use this term here to indicate space, not as a particular criterion, but as the resultant of a special morphological configuration. 

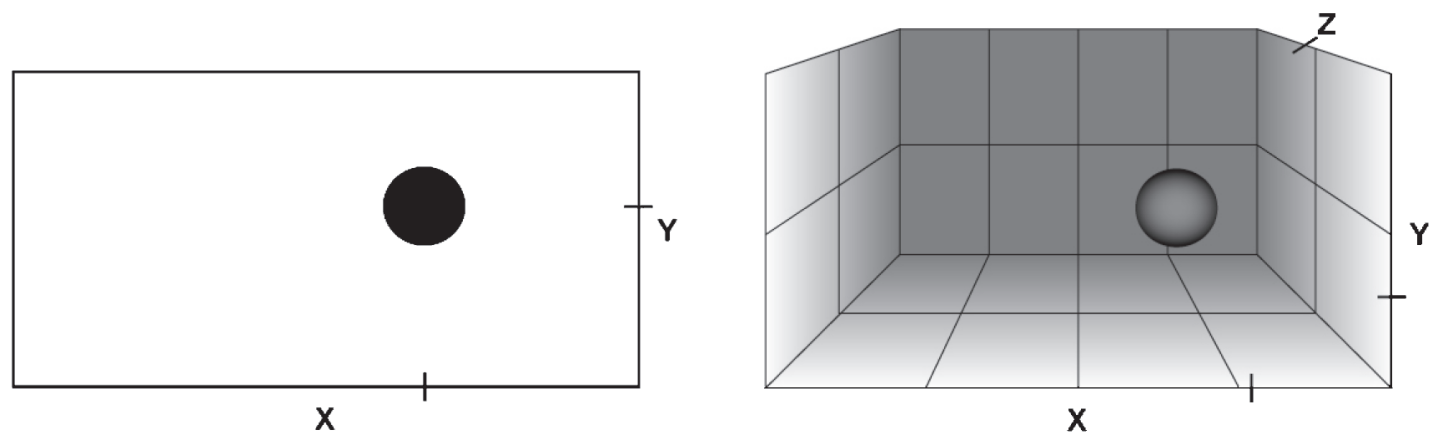

Figures 1 and 2. Plans of the representation of two and three dimensions.
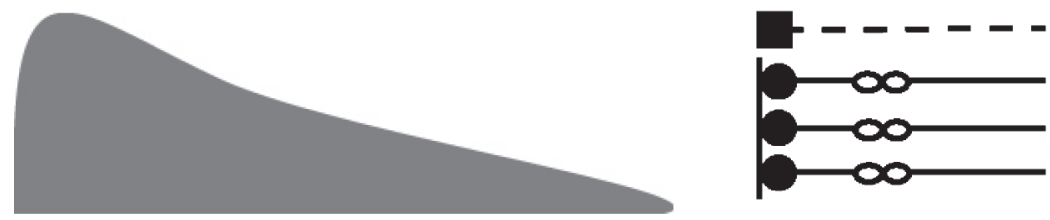

Figures 3 and 4. Iconic and symbolic representation.

highlighting the iconic and symbolic functions of signs. This means that our graphical objects will have iconic functions (figure 3) - the link between graphical qualities and the sound criteria they represent are relatively intuitive: for example the shape of the dynamical envelope - or symbolic functions (figure 4: an example of a symbol by Lasse Thoresen) - the graphical form will be the result of a very precise coding of sound criteria; here, the result is often complicated to read as it demands familiarity with the legend.

If symbolic representations enable significant analytical accuracy, they also entail a highly reduced potential public, as the complex decoding of each symbol is principally of interest to specialists. Inversely, iconic representations do not always need a legend as the relations between sound and graphical forms are much more intuitive. Moreover, it is possible to achieve great precision and great analytical complexity using this principle whilst remaining as clear as possible. Until now I have been particularly interested in this last type of representation. Its didactical and aesthetical qualities represent undeniable advantages in the transmission of analysis. Furthermore, it can be integrated perfectly into multimedia, as its very existence is based on a very strong relation between image and sound. I think it would now be appropriate to follow on this research with an association of iconic and symbolic functions. This will enable multi-faceted representations to be constructed, each presenting a specific insight into the work, for a specific public.

So, let us take a deeper look at an explanation of the iconic functions of representations. Figure 5 demonstrates the different graphical qualities of an object extracted from a representation (figure 6). Each of
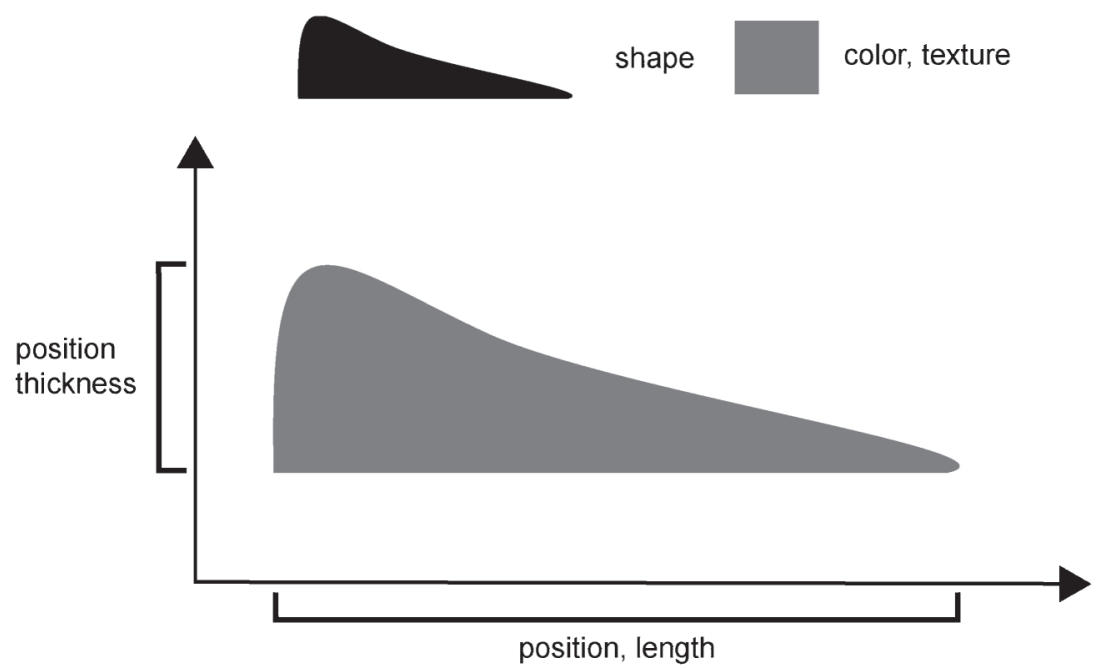

Figure 5. Graphical qualities of an object. 


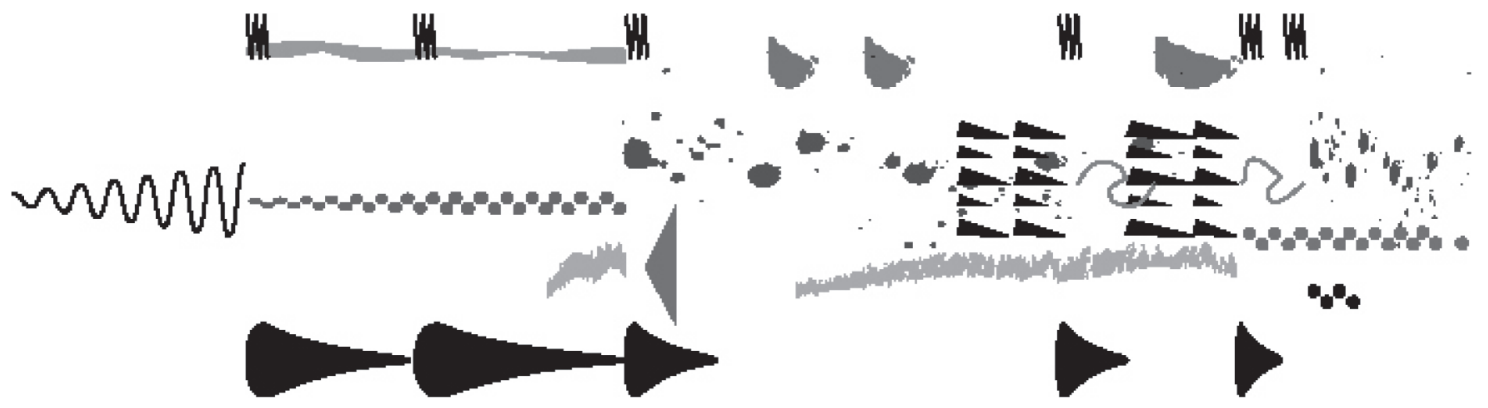

Figure 6. Ionic representation of Reflet by Ivo Malec ( $\left.0^{\prime} 00^{\prime \prime}-1^{\prime} 00^{\prime \prime}\right)$.

object 1

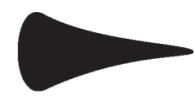

object 2

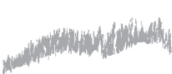

vertical arrangement : pitch thickness : dynamic shape length : duration shape : sound of plucked string

thickness : spectral thickness length : duration shape : sound of friction texture : granular sound

Figure 7. Relations between image and sound in two of the graphical objects of figure 6 .

these qualities can be associated with one or several sound criteria.

Figure 7 analyses two graphical objects extracted from figure 6 for which the different criteria are indicated. Thus, it is easy to understand the relations between image and sound.

The didactical qualities of such a representation are obvious: listening repeatedly whilst following the graphics enables the sounds, structures and even some of their more difficult qualities (which often escape the neophyte) to be identified. But representation is also an analytical tool that allows a researcher to refine his listening of the work by attempting to distinguish which graphic can be associated to which sound and why.

\section{WHY IS REPRESENTATION NECESSARY?}

Having defined representation, as I consider it, I will now go on to explore its different functions: a quick annotation for the first listening, a listening guide, an analytical aid or annotation for a playing. The common denominator seems to be the assistance it offers to audio appreciation. Whether it be the analyst, the musicologist, the experienced listener or the neophyte, each uses representation to guide his listening. Considering the analyst, it is possible to decompose his work into four phases: a first quick annotation of the material's main features (figure 8), a precise segmentation of the sounds or basic sound structures (figure 9), an analysis of the structures (figure 10) and a final representation of the analysis (figure 6).

Now let us consider the neophyte listener. His listening is organised according to the representation: each listening allows him to delve deeper into the material and into the structures of the work. It is possible to detail the different phases of his listening process (figure 11): an appreciation of the links between graphics and sound (segmentation), the association and comparison of the sounds themselves in relation to the graphics (paradigmatic analysis) and an anticipation of the listening which, itself, confirms or not, the identification of graphical forms.

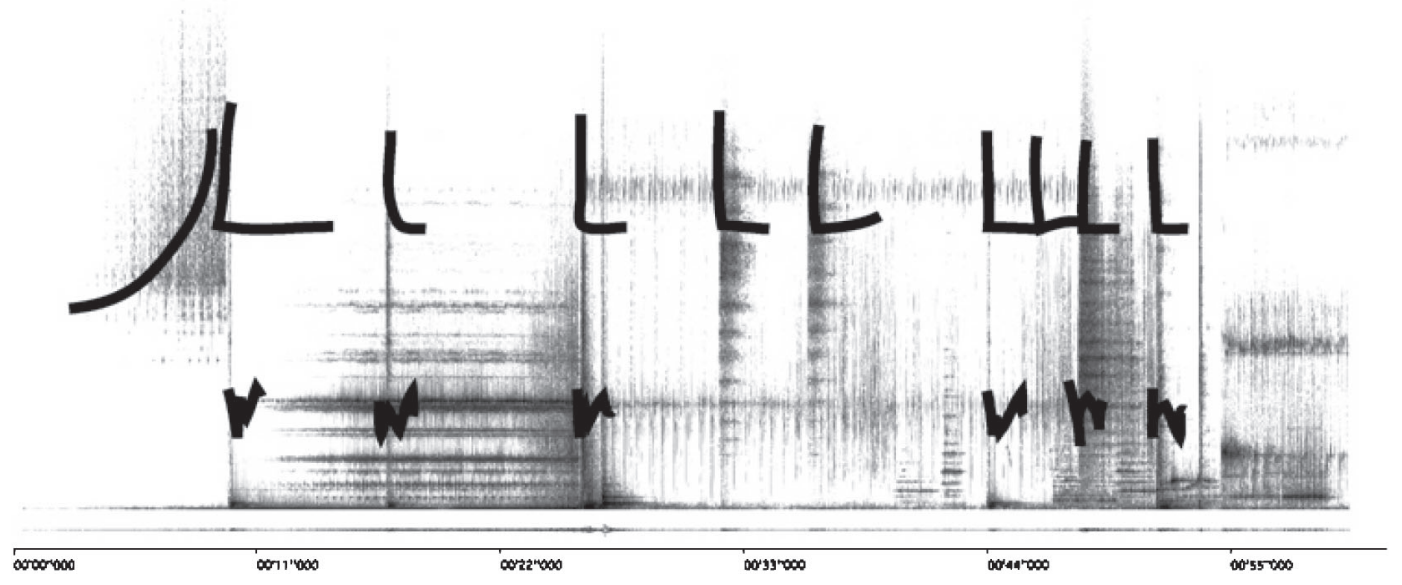

Figure 8. First quick annotation of the sonogram of Reflet by Ivo Malec $\left(0^{\prime} 00^{\prime \prime}-1^{\prime} 00^{\prime \prime}\right)$. 


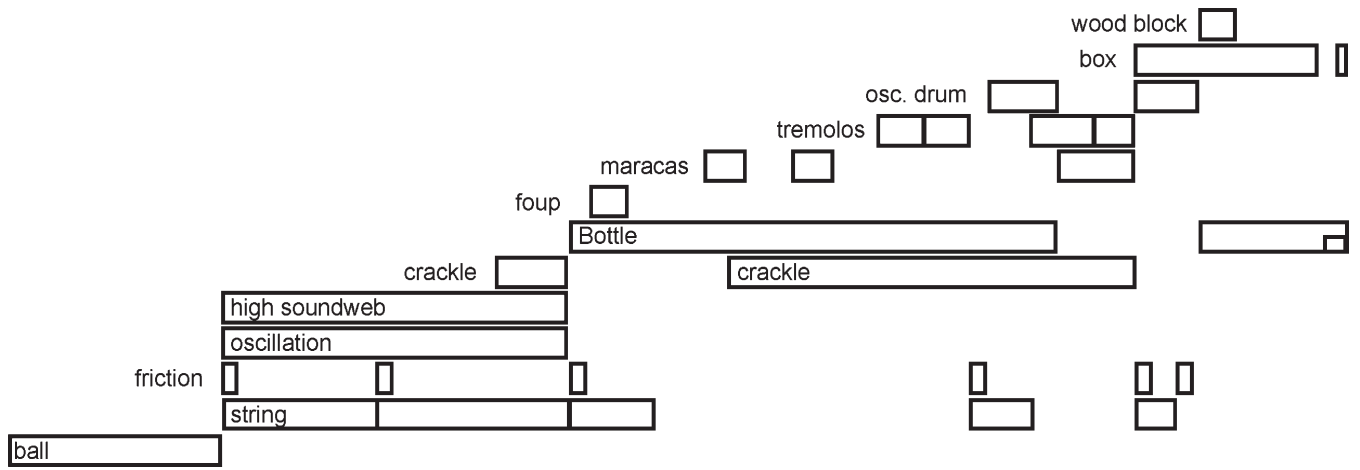

Figure 9. detailed segmentation of Reflet by Ivo Malec ( $\left(0^{\prime} 00^{\prime \prime}-1^{\prime} 00^{\prime \prime}\right)$.

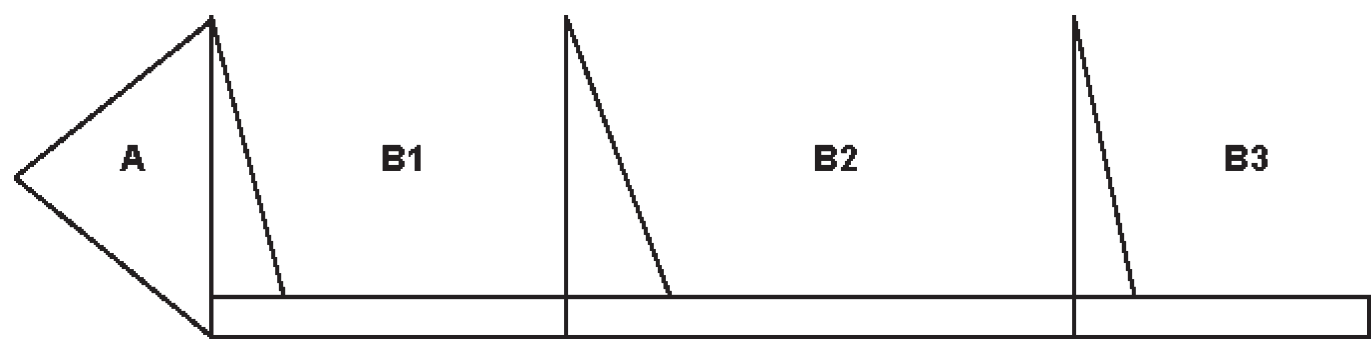

Figure 10. Structure of Reflet by Ivo Malec (0'00"-1'00").

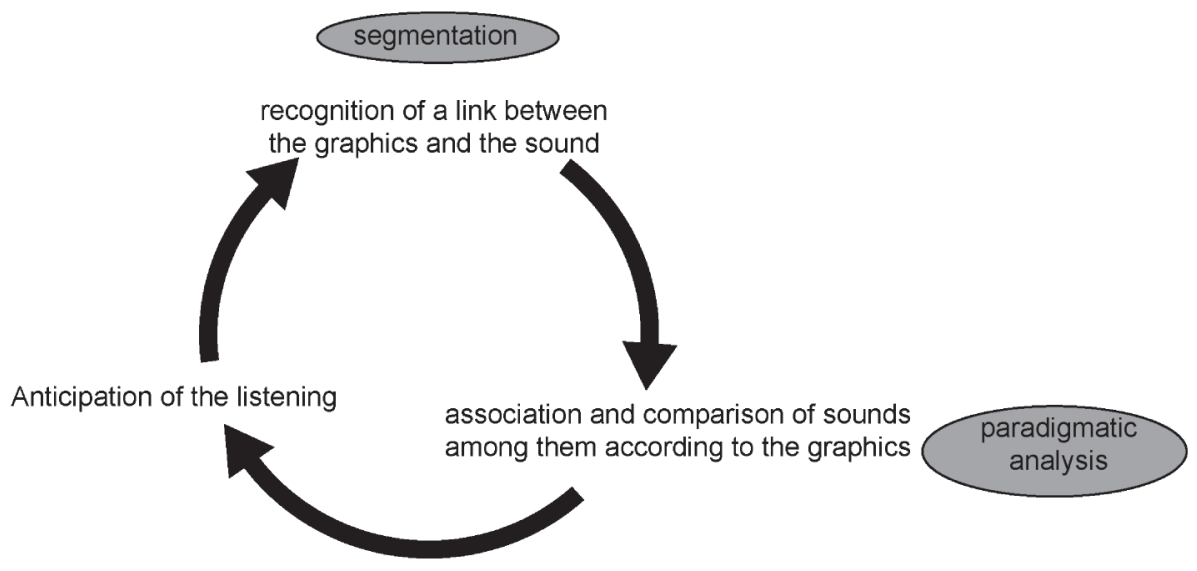

Figure 11. the auditor's listening using graphical representation.

As I mentioned previously, for the neophyte auditor, iconic graphical representation is an extremely useful tool. But it must not be forgotten that it is just a tool and that graphics cannot replace the actual work; they are simply a guide which provides the listener with the keys to listening to a work.

\section{HOW TO REPRESENT?}

This, the final part, will be consecrated to the work of the analyst. However, this explanation of the representational method can be perfectly adapted to working with non-specialists. As a teacher, I have already successfully tested this method several times with children.

The first step is to evaluate the level of segmentation. Pierre Schaeffer has theorised this problem via the dualism of object/structure, without however providing the answer. Everything depends on the level of the analysis, the idea to be developed and the sound complexity of the work. It is often better to carry out several segmentations in order to find the one that best reveals the fundamental material. But often, I use a much easier technique. It involves annotating the sonogram with very simple symbols or text (figure 8). From this first annotation, it is easy to construct an 


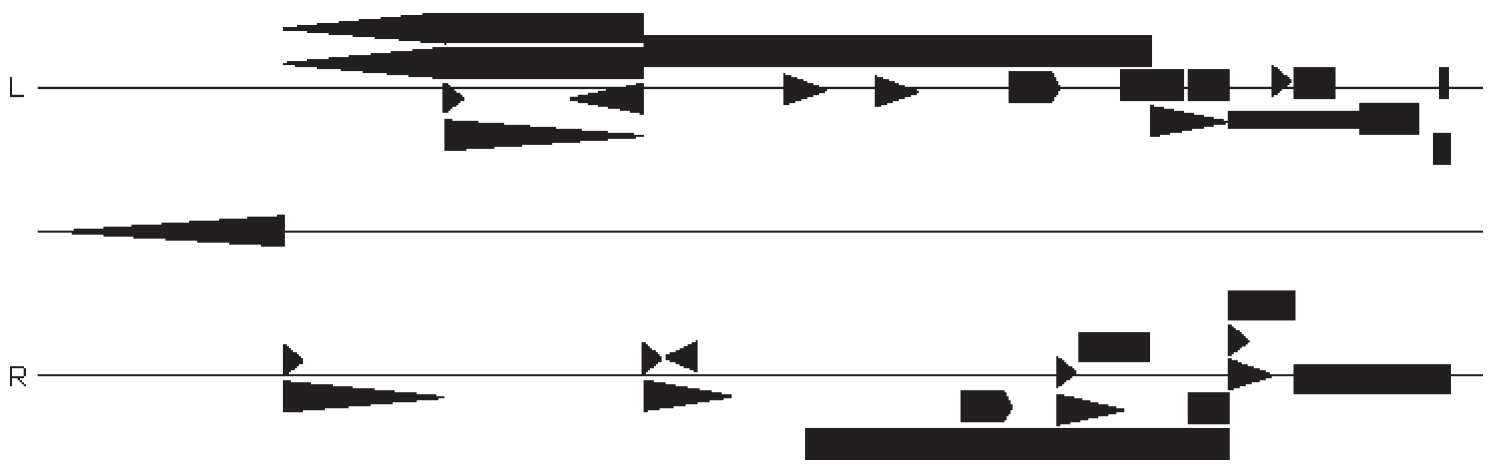

Figure 12. Representation of the dynamical envelope and space in Reflet by Ivo Malec ( $\left(0^{\prime} 00^{\prime \prime}-1^{\prime} 00^{\prime \prime}\right)$.

initial paradigmatic scheme (incomplete): columns represent the different sound types, reiterations of these sounds with modifications are compiled little by little in these columns. It is this first step that allows graphics to be created, which correspond to each of the sounds: certain sound criteria and the modifications that appear throughout the work are taken into account, in order to create an ensemble of symbols, in which the characteristics are perfectly identifiable. Acousmographe software ${ }^{2}$ allows the symbols to be created and set down onto the representation with perfect temporal synchronisation (figure 6).

When carrying out a precise analysis of the material, it is sometimes better to create several representations, each analysing a collection of criteria and acting as complementary to one and other. The symbols of figure 12 were created according to dynamic envelopes and were then positioned according to the spatial position of the sound (right, centre, left).

Multiple representations can also be the result of the work of different analysts. This creates a plurality of points of view, which mutually enrich one another and result in an extremely rich analytical object. The Entendre part of the La musique électroacoustique CD-ROM illustrates this idea perfectly.

\section{CONCLUSION}

This short article has allowed me to demonstrate how graphical representation could prove to be an analytical tool, perfectly adapted to electroacoustic music. The creation of symbols and their positioning demands a precise analysis of the sounds and musical structures of the work. What is more, representation is an analytical method, well adapted to multimedia publication: the association of sound, graphics and text creates an analytical object accessible to both the neophyte and the specialist. Furthermore, representation can also be used to assist 'listening education', for example when teaching children. The creation of the visual provokes an enrichment of the listening.

\section{REFERENCES}

Battier, M., and Couprie, P. 1999. L'Acousmographe: un outil pour l'analyse informatique de documents sonores. Les cahiers de l'OMF 4.

Collectif. 2000. La Musique électroacoustique. Paris: INAGRM/Hyptique.

Collectif. Portraits polychromes. Paris: INA/GRM-CDMC. http://www.ina.fr/grm/acousmaline/polychromes/ index. fr.html.

Couprie, P. 1999. Three analysis models for L'Oiseau moqueur, one of the Trois rêves d'oiseau by François Bayle. Organised Sound 4: S1.

Couprie, P. 2003. Analyse comparée des Trois rêves d'oiseau de François Bayle. Demeter. http://www.univ-lille3.fr/ revues/demeter/.

Delalande, F. 1986. En l'absence de partition, le cas singulier de l'analyse de la musique électroacoustique. Analyse musicale 3.

Eco, U. 1980. Le Signe. Paris: Le Livre de Poche.

Helmuth, M. 1996. Multidimensional representation of electroacoustic music. Journal of New Music Research 25.

Mion, P., Nattiez, J. J., and Thomas, J. C. 1982. L'Envers d'une æuvre. de Natura Sonorum de Bernard Parmegiani. Paris: INA-GRM/Buchet Chastel.

Roy, S. 1993. Analyse des œuvres acousmatiques: quelques fondements et proposition d'une méthode. Circuit 4: S1-2.

Thoresen, L. 1986. Auditive analysis of musical structures. A summary of analytical terms, graphical signs and definitions. ICEM Conf. on Electro-acoustic Music.

Tiercelin, C. 2002. La Sémiotique philosophique de Charles Sanders Peirce. In A. Hénault (ed.) Questions de Sémiotique. Paris: PUF. 